Article

\title{
Convenient and Efficient Microwave-Assisted Synthesis of a Methyl Derivative of the Fused Indoloquinoline Alkaloid Cryptosanguinolentine
}

\author{
Robert M. Gengan ${ }^{1, *}$, Pitchai Pandian ${ }^{1,2, *}$, Chandraprakash Kumarsamy ${ }^{2}$ and \\ Palathurai S. Mohan ${ }^{2}$
}

1 Department of Chemistry, Steve Biko Campus, Durban University of Technology, Durban-4001, South Africa

2 Department of Chemistry, School of Chemical Sciences, Bharathiar University, Coimbatore641046, Tamil Nadu, India; E-Mail: ps_mohan_in@yahoo.com (P.S.M.)

* Author to whom correspondence should be addressed; E-Mails: genganrm@dut.ac.za (R.M.G.); pitchaipandian@gmail.com (P.P.); Tel.: +27 313732309; Fax: +27 312022671.

Received: 10 March 2010; in revised form: 2 April 2010 / Accepted: 7 April 2010 /

Published: 29 April 2010

\begin{abstract}
An efficient synthesis of a methyl derivative of the indoloquinoline alkaloid cryptosanguinolentine based on microwave-assisted reactions is described. The microwave-assisted synthesis of an intermediate 4-hydroxy-2-methylquinoline yielded $86 \%$ of the desired product and other intermediates prepared yielded high $\%$ of products in shorter reaction times, under optimum conditions, as compared to traditional methods.
\end{abstract}

Keywords: cryptosanguinolentine; microwave; phase transfer catalysis

\section{Introduction}

The roots of Cryptolepis sanguinolenta, a plant indigenous to West Africa [1,2] have been used by Ghanian traditional healers to treat various disorders, including outbreaks of fever due to malaria and urinary tract infections [3-5]. The efficacy of a concoction of the roots stimulated researchers to isolate the organic components present, characterize their structures and elucidate their biological activities. Alkaloids such as the angular fused indoloquinoline alkaloid cryptosanguinolentine and the linear indoloquinoline alkaloids cryptolentine and cryptotackieine were isolated and characterized [6]. These 
compounds exhibit strong antiplasmodial activity and behave as DNA intercalating agents, thereby inhibiting DNA replication and transcription. Crypto-sanguinolentine, a planar aromatic compound with functional groups at positions suitable for intercalating with a DNA helix and thereby altering the conformation of this helix [6] has received significant attention. Methyl derivatives of these types of indoloquinoline alkaloids have been reported $[7,8]$ to act as cytotoxic agents, liposomally-formulated anticancer agents [9], and DNA-topoisomerase II inhibitors [10].

According to literature, the synthesis of cryptosanguinolentine by an intramolecular reaction of an iminophosphorane with an isocyanate [11-13], by the regioselective thermocyclization of the corresponding azide [14] or by ortho-metalation using a cross-coupling strategy [15] was used in the 1990s. Our research thrust in the synthesis of cryptosanguinolentine was initially based on a three step photo-induced cyclization reaction giving excellent yield [16]. We subsequently developed a convenient and efficient three step procedure using the Fischer indole strategy [17] which gave the products in high yield. The Fischer indole methodology is one of the most important processes in heterocyclic chemistry, leading to a large variety of hetero-polycyclic biologically active compounds containing the indole nucleus and in some cases is the only method available for reaching target structures. Our subsequent report on the synthesis of the methyl derivative of cryptosanguinolentine was via a heteratom-directed photoannulation technique [18]. Recently we reported a five step procedure using a simple starting material, viz., $\beta$ anilinocrotonate, with the aid of a photochemical reactor and a domestic microwave [19]. In continuation with the synthesis of the methyl derivative of cryptosanguinolentine we herein report a more efficient synthetic scheme using microwave assisted reactions to produce high yields of the intended products. The main benefits of performing reactions under microwave conditions are the significant enhancement of reaction rates, higher product yields as well as conforming to global demands for the use of green technology.

\section{Results and Discussion}

The optimum microwave conditions for the preparation of 4-hydroxy-2-methylquinoline (2) from $\beta$ anilinocrotonate (1) (Scheme 1) were optimised; compound 1 was heated directly without any solvent for three minutes at 250 watts and $180^{\circ} \mathrm{C}$. The solid was collected, purified and the yield recorded as $86 \%$. Compound 2 was confirmed by its IR spectrum, which exhibited a broad characteristic O-H stretch at 3,062 $\mathrm{cm}^{-1}$ and $\mathrm{CH}_{3} \mathrm{C}-\mathrm{H}$ stretching at $2,767 \mathrm{~cm}^{-1}$; its ${ }^{1} \mathrm{H}-\mathrm{NMR}$ spectrum displayed a $\mathrm{CH}_{3}$ singlet at $\delta 2.49$, and a broad singlet at $\delta 11.60$ for the O-H proton. Our earlier investigations [19] of the yield of 2 via a domestic microwave was marginally lower $(80 \%)$.

3-Iodo-4-hydroxy-2-methylquinoline (3) was prepared from the reaction of 2 with a mixture of iodine, potassium iodide and sodium hydroxide in tetrahydrofuran. The product identity was confirmed from its ${ }^{1} \mathrm{H}-\mathrm{NMR}$ data by the disappearance of the singlet at $\delta 5.90$ due to the C-3 proton of the 4quinolone. Thereafter 3 was refluxed with phosphorous oxychloride under microwave irradiation for 1 minute at 150 watts and $85{ }^{\circ} \mathrm{C}$ to produce 4 in $95 \%$ yield. The yield was the same as our previous report [19], however the reaction time was significantly reduced compared to the classic solvent reflux methodology. Compound 4 was confirmed by its IR spectrum which showed the appearance of C-Cl stretching at $758 \mathrm{~cm}^{-1}$, as well as the disappearance of the broad $\mathrm{OH}$ signal. This was further confirmed 
by the disappearance of the $\mathrm{OH}$ peak in the ${ }^{1} \mathrm{H}-\mathrm{NMR}$ spectrum and the appearance of $\delta 110.78$ for the corresponding carbon in ${ }^{13} \mathrm{C}$-NMR spectrum.

The amination of $\mathbf{4}$ to $\mathbf{5}$ was a simple room temperature reaction performed by stirring $\mathbf{4}$ in a mixture of aniline in ethanol to produce a pale yellow solid 5; this was recrystallized from chloroform and the yield recorded as $98 \%$. The characteristic N-H stretching at $3334 \mathrm{~cm}^{-1}$ in the IR spectrum, a broad singlet at $\delta 8.56$ for the N-H proton in the ${ }^{1} \mathrm{H}-\mathrm{NMR}$ and $\mathrm{C}_{3}$ signal at $\delta 51.97$ in the ${ }^{13} \mathrm{C}-\mathrm{NMR}$ spectrum confirms the identity of compound 5 .

For the next step in the reaction scheme, compound 5 was taken in up water and mixed with triphenylphosphine, sodium carbonate, palladium acetate with tricaprylyl methyl ammonium chloride (TCMAC) and was refluxed at $80^{\circ} \mathrm{C}$ under microwave irradiation. The spectral data of 6 matched the compound obtained from the photochemical cyclization method we reported recently [19]; the elimination of iodine due to ring closure was confirmed by the appearance of a C-3 signal at $\delta 126.73$ in the ${ }^{13} \mathrm{C}$-NMR spectrum. The yield ( $\left.83 \%\right)$ of 6 was higher than that obtained by the photochemical procedure. To our knowledge, this is the first time this cyclization reaction has been performed. The improved yield is due to the eco-friendly methodology that we used: a microwave assisted reaction using water as the solvent, phase transfer catalysis, and palladium acetate catalysis for a regio- and stereoselective product.

Scheme I. Synthesis of 5,6-dimethyl-5H-indolo[3,2-c]quinoline 7 from $\beta$-anilinocrotonate 1 .

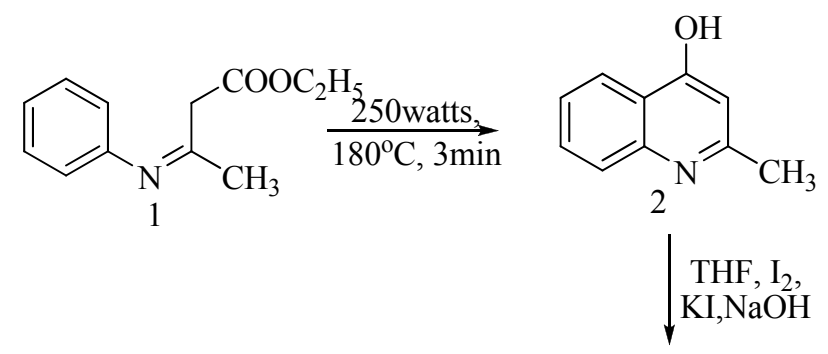<smiles>Cc1nc2ccccc2c(Cl)c1I</smiles><smiles>Cc1nc2ccccc2c(Nc2ccccc2)c1I</smiles><smiles>Cc1c2ccccc2nc2c1c(=O)n(C)c1ccccc21</smiles> 
The final step in the synthesis of the methyl substituted cryptosanguinolentine 7 involved selective methylation of the $N$ atom of the quinoline skeleton. This was accomplished by reacting 6 with dimethyl sulphate and potassium carbonate under microwave conditions $\left(250\right.$ watts, $120^{\circ} \mathrm{C}$ for $3 \mathrm{~min}$ ). The yield of 7 however, was marginally higher than in our previous report [19]. The methylation product was confirmed by the appearance of a singlet at $\delta 3.75$ in the ${ }^{1} \mathrm{H}-\mathrm{NMR}$ spectrum.

\section{Experimental Section}

\subsection{General methods}

Melting points are uncorrected. Infrared spectra were recorded on a Perkin-Elmer Paragon 1000 FTIR spectrophotometer as potassium bromide discs, unless otherwise indicated. ${ }^{1} \mathrm{H}-\mathrm{NMR}$ spectra were obtained on a Bruker $500 \mathrm{MHz}, 400 \mathrm{MHz}$ or $300 \mathrm{MHz}$ instrument in either $\mathrm{CDCl}_{3}$ or DMSO-D solutions using tetramethylsilane as an internal standard. $J$ Values are given in Hz. Mass spectra were obtained at the Indian Institute of Chemical Technology, Hyderabad, India. Column chromatography utilized Merck silica gel 60 and hexane and ethyl acetate as eluants. All the basic chemicals were purchased from Merck (South Africa) and Fluka (South Africa). The Microwave used is a CEM Microwave synthesizer.

\subsection{Preparation of $\beta$-anilinocrotonate (1)}

Freshly distilled aniline $(0.25 \mathrm{~mol})$ and ethyl acetoacetate $(0.25 \mathrm{~mol})$ were mixed, $5-10$ drops of concentrated hydrochloric acid was added and the mixture was gently shaken at room temperature. This mixture was left aside and within a few minutes it became turbid thereby indicating the liberation of water due to a condensation reaction. At this stage, the mixture was placed inside a vacuum desiccator over concentrated sulphuric acid and kept for 2-3 days. A deep yellow oily liquid 1, was separated and dried over anhydrous sodium sulphate.

\subsection{Synthesis of 4-hydroxy-2-methylquinoline (2)}

Dried ethyl- $\beta$-anilinocrotonate $(1,25 \mathrm{~mL})$ was subjected to microwave heating for $3 \mathrm{~min}$ at 250 watts and $150{ }^{\circ} \mathrm{C}$ in the synthetic microwave oven. The solid formed was washed with ethyl acetate $(200 \mathrm{~mL})$, followed by a mixture of chloroform and petroleum ether (30:10) to give a pure white powder. Yield $11.82 \mathrm{~g}$ (86\%); m.p. $256^{\circ} \mathrm{C}$; IR (KBr) [v $\left.v_{\max } \mathrm{cm}^{-1}\right] 3062(\mathrm{O}-\mathrm{H}), 2767(\mathrm{C}-\mathrm{H}) ;{ }^{1} \mathrm{H}-$ NMR (DMSO-D, 300 MHz, DMSO-D $6=2.50$ ppm) $\delta 2.49\left(\mathrm{~s}, 3 \mathrm{H}, \mathrm{CH}_{3}\right), \delta 5.90(\mathrm{~s}, 1 \mathrm{H}, \mathrm{H}-3), \delta 7.26$ (t, 1H, H-6), $\delta 7.49$ (d,1H, H-5, $J=7.2 \mathrm{~Hz}), \delta 7.60$ (t, 1H, H-7, $J=7.6 \mathrm{~Hz}), \delta 8.02$ (d,1H, H-8, $J=8.0 \mathrm{~Hz}), \delta 11.60(\mathrm{bs}, 1 \mathrm{H}, \mathrm{OH})$.

\subsection{Synthesis of 4-hydroxy-3-iodo-2-methylquinoline (3)}

A mixture of 2-phenylquinolin-4(1H)-one $2(0.5 \mathrm{~g}, 2.26 \mathrm{mmol})$, iodine (1.15 g, $4.52 \mathrm{mmol})$ and sodium carbonate $(0.36 \mathrm{~g}, 3.43 \mathrm{mmol})$ in THF $(20 \mathrm{~mL})$ was stirred at room temperature for $12 \mathrm{~h}$ and 
then poured into a saturated ice-cold aqueous sodium thiosulphate solution. The precipitate was collected, washed with water and recrystallized to afford compound 3. Yield $0.920 \mathrm{~g}$ (75\%);

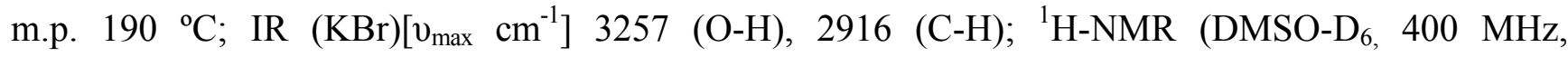
DMSO-D $\left._{6}=2.50 \mathrm{ppm}\right) \delta 2.49\left(\mathrm{~s}, 3 \mathrm{H}, \mathrm{CH}_{3}\right), \delta 7.37\left(\mathrm{t}, 1 \mathrm{H}, \mathrm{C}_{6}-\mathrm{H}, J=7.2 \mathrm{~Hz}\right), \delta 7.55(\mathrm{~d}, 1 \mathrm{H}, \mathrm{H}-5$, $J=8.4 \mathrm{~Hz}), \delta 7.69$ (t, 1H, H-7, $J=8.0 \mathrm{~Hz}), \delta 8.09$ (d, 1H, H-8, $J=8.0 \mathrm{~Hz}), \delta 12.20(\mathrm{~s}, 1 \mathrm{H}, \mathrm{OH})$.

\subsection{Synthesis of 4-chloro-3-iodo-2-methylquinoline (4)}

A mixture of 4-hydroxy-3-iodo-2-methylquinoline (3, $1.43 \mathrm{~g}, 0.005 \mathrm{~mol})$ in phosphorus oxychloride $(4 \mathrm{~mL})$ was heated under reflux for $1 \mathrm{~min}$ at 150 watts and $80{ }^{\circ} \mathrm{C}$. The mixture was cooled to room temperature, slowly added to ice-water and neutralized with a dilute $\mathrm{NaOH}$ solution. The precipitate thus obtained was filtered and dried. Yield $1.42 \mathrm{~g}(95 \%)$; m.p. $70^{\circ} \mathrm{C}$; IR $(\mathrm{KBr})\left[v_{\max } \mathrm{cm}^{-1}\right] 1550(\mathrm{C}=\mathrm{N})$, 1338 (C-I), $758(\mathrm{C}-\mathrm{Cl}) ;{ }^{1} \mathrm{H}-\mathrm{NMR}\left(\mathrm{CDCl}_{3}, 400 \mathrm{MHz}, \mathrm{CDCl}_{3}=7.24 \mathrm{ppm}\right) \delta 3.02\left(\mathrm{~s}, 3 \mathrm{H}, \mathrm{CH}_{3}\right), \delta 7.56(\mathrm{t}$, $1 \mathrm{H}, \mathrm{H}-6, J=7.2 \mathrm{~Hz}), \delta 7.74(\mathrm{t}, 1 \mathrm{H}, \mathrm{H}-7, J=8.0 \mathrm{~Hz}), \delta 8.00$ (d, 1H, H-5, $J=8.0 \mathrm{~Hz}), \delta 8.20$ (d, $1 \mathrm{H}, \mathrm{H}-$ $8, J=8.0 \mathrm{~Hz}) ;{ }^{13} \mathrm{C}-\mathrm{NMR}\left(\mathrm{CDCl}_{3}, 100 \mathrm{MHz}, \mathrm{CDCl}_{3}=70.00 \mathrm{ppm}\right) \delta 155.13(\mathrm{C}-2), 27.34\left(\mathrm{CH}_{3}\right), 110.78$ (C-3), 157.50 (C-4), 131.77 (C-4a), 120.45 (C-5), 124.33 (C-6), 127.62 (C-7), 129.15 (C-8), 149.34 (C8a), 144.79 (C-1'), 119.42 (C-2' \& C-2'”), 115.71(C-3'\& C-3' '), 120.11 (C4').

\subsection{Synthesis of 4-anilino-3-iodo-2-methylquinoline (5)}

4-Chloro-3-iodo-2-methylquinoline $(4,1.51 \mathrm{~g}, 0.005 \mathrm{~mol})$ and aniline $(0.93 \mathrm{~mL}, 0.01 \mathrm{~mol})$ were dissolved in dry ethanol $(30 \mathrm{~mL})$. The initial colour of the reaction mixture was colourless, but changed into yellow after some $15 \mathrm{~min}$. The reaction was monitored by thin layer chromatography (tlc) and the formation of product was confirmed by the appearance of a new spot with $\mathrm{Rf}$ equal to the standard. The reaction mixture was stirred for a further $30 \mathrm{~min}$, filtered, dried and recrystallized from chloroform. Yield 1.29 g (98\%); m.p. $180{ }^{\circ} \mathrm{C}$; IR (KBr) $\left[v_{\max } \mathrm{cm}^{-1}\right] 3334(\mathrm{~N}-\mathrm{H}) ;{ }^{1} \mathrm{H}-\mathrm{NMR}\left(\mathrm{CDCl}_{3}\right.$, $\left.400 \mathrm{MHz}, \mathrm{CDCl}_{3}=7.24 \mathrm{ppm}\right) \delta 3.18\left(\mathrm{~s}, 3 \mathrm{H}, \mathrm{CH}_{3}\right), \delta 7.07$ (d, 2H, Ph-H-2'\& H-2", $\left.J=8.0 \mathrm{~Hz}\right), \delta 7.22$ (t, 2H, H-3'\& H-3"' $J=8.0$ Hz), $\delta 7.38$ (m, 3H, H-5, H-6 \& H-7, $J=8.0$ Hz), $\delta 7.54$ (d, 1H, H-8, $J=8.0 \mathrm{~Hz}), \delta 7.72\left(\mathrm{t}, 1 \mathrm{H}, \mathrm{H}-4^{\prime}, J=7.2 \mathrm{~Hz}\right), \delta 8.56(\mathrm{bs}, 1 \mathrm{H}, \mathrm{NH}) ;{ }^{13} \mathrm{C}-\mathrm{NMR}\left(\mathrm{CDCl}_{3}, 100 \mathrm{MHz}\right.$, $\left.\left.\mathrm{CDCl}_{3}=70.00 \mathrm{ppm}\right) \delta 159.01(\mathrm{C}-2), 13.05\left(\mathrm{CH}_{3}\right), 51.97(\mathrm{C}-3), 148.27(\mathrm{C}-4), 125.16 \mathrm{C}-4 \mathrm{a}\right)-, 124.33$ (C-6), 129.76 (C-7 \& C-8), 147.39 (C-8a), 131.08 (C-1'), 96.43 (C-2'\& C-2'), 129.46 (C-3' \& C-3'), $125.82\left(\mathrm{C}-4^{\prime} \& \mathrm{C}-5\right)$.

\subsection{Synthesis of 6-methyl-11H-indolo[3,2-c]quinoline (6)}

A mixture of compound 5 (1.96 g, $0.0024 \mathrm{~mol})$, triphenylphosphine $(0.12 \mathrm{~g}, 0.0046 \mathrm{~mol})$, palladium(II) acetate $(0.03 \mathrm{~g}, 0.0001 \mathrm{~mol})$ and sodium hydrogen carbonate $(0.62 \mathrm{~g}, 0.0074 \mathrm{~mol})$ and tricaprylmethylammonium chloride as phase transfer catalyst was refluxed in water at $100{ }^{\circ} \mathrm{C}$ for $5 \mathrm{~min}$ at 200 watts. The mixture was allowed to cool to room temperature, poured into water and then acidified to $\mathrm{pH} 2-3$ with dilute hydrochloric acid. The mixture was extracted several times with ethyl acetate and the combined organic extracts were washed with water, dried with anhydrous sodium sulphate, filtered and evaporated under reduced pressure giving 6-methyl-11H-indolo[3,2-c]quinoline 
(6). Yield 0.95 g (83\%); m.p. $210{ }^{\circ} \mathrm{C}$; IR $(\mathrm{KBr})\left[\mathrm{v}_{\max } \mathrm{cm}^{-1}\right] 3307$ (N-H); ${ }^{1} \mathrm{H}-\mathrm{NMR}$ (DMSO-D $\left.500 \mathrm{MHz}, \mathrm{DMSO}_{-} \mathrm{D}_{6}=2.50 \mathrm{ppm}\right) \delta 2.43\left(\mathrm{~s}, 3 \mathrm{H}, \mathrm{CH}_{3}\right), \delta 7.33-7.88(\mathrm{~m}, 7 \mathrm{H}, \mathrm{Ar}-\mathrm{H}), \delta 8.07(\mathrm{~d}, 1 \mathrm{H}, \mathrm{H}-$ 4), $\delta 10.51(\mathrm{bs}, 1 \mathrm{H}, \mathrm{NH}) ;{ }^{13} \mathrm{C}-\mathrm{NMR}\left(\mathrm{DMSO}_{6}, 125 \mathrm{MHz}, \mathrm{DMSO}-\mathrm{D}_{6}=40.0 \mathrm{ppm}\right) \delta 127.41(\mathrm{C}-1), \delta$ $124.69(\mathrm{C}-2), \delta 126.73(\mathrm{C}-3), \delta 129.44(\mathrm{C}-4), \delta 150.17(\mathrm{C}-4 \mathrm{a}), \delta 154.75(\mathrm{C}-6), \delta 23.14\left(\mathrm{CH}_{3}\right), \delta$ 122.57 (C-6a), $\delta 126.78$ (C-6b), $\delta 120.29$ (C-7), $\delta 124.43$ (C-8), $\delta 119.54$ (C-9), $\delta 118.64$ (C-10), $\delta$ 135.67 (C-10a), $\delta 136.73$ (C-11a), $\delta 130.11$ (C-11b).

\subsection{Synthesis of 5,6-dimethyl-5H-indolo[3,2-c]quinoline (7)}

A mixture of compound 6 with dimethyl sulphate $(1.5 \mathrm{~mL})$ was taken up in dimethylformamide $(10 \mathrm{~mL})$ and potassium carbonate $(500 \mathrm{mg})$ was added. The whole mixture was subjected to microwave heating for $3 \mathrm{~min}$ at 250 watts and $120{ }^{\circ} \mathrm{C}$. The completion of the reaction was monitored by tlc. The mixture was then poured into crushed ice $(300 \mathrm{~mL})$ and extracted with ethyl acetate $(100 \mathrm{~mL} \times 3)$. The combined organic layers was subjected to silica gel column chromatography with a gradient elution with petroleum ether and ethyl acetate in a 35:65 ratio, and the mass of 5,6-dimethyl$5 H$-indolo[3,2-c] quinoline (7) was recorded. Yield $1.08 \mathrm{~g}(86 \%)$; m.p. $189{ }^{\circ} \mathrm{C}$; IR $(\mathrm{KBr})\left[\mathrm{v}_{\max } \mathrm{cm}^{-1}\right]$ $1626(\mathrm{C}=\mathrm{N}) ;{ }^{1} \mathrm{H}-\mathrm{NMR}\left(\mathrm{DMSO}_{6}, 500 \mathrm{MHz}, \mathrm{DMSO}_{6}=2.50 \mathrm{ppm}\right) \delta 2.43\left(\mathrm{~s}, 3 \mathrm{H}, \mathrm{C}_{6}-\mathrm{CH}_{3}\right), \delta 3.75$ $\left(\mathrm{s}, 3 \mathrm{H}, \mathrm{C}_{5}-\mathrm{CH}_{3}\right), \delta 7.36-7.92(\mathrm{~m}, 7 \mathrm{H}, \mathrm{Ar}-\mathrm{H}), \delta 8.26(\mathrm{~d}, 1 \mathrm{H}, \mathrm{H}-4, J 8.2 \mathrm{~Hz}) ;{ }^{13} \mathrm{C}-\mathrm{NMR}\left(\mathrm{DMSO}_{6} \mathrm{D}_{6}, 125\right.$ MHz, DMSO-D $=40.0$ ppm) $\delta 127.41(\mathrm{C}-1), \delta 124.69(\mathrm{C}-2), \delta 126.73(\mathrm{C}-3), \delta 129.44(\mathrm{C}-4), \delta$ $150.17(\mathrm{C}-4 \mathrm{a}), \delta 154.75(\mathrm{C}-6), \delta 23.14\left(\mathrm{CH}_{3}\right), \delta 122.57$ (C-6a), $\delta 126.78$ (C-6b), $\delta 120.29(\mathrm{C} 7), \delta$ 124.43 (C-8), $\delta 119.54(\mathrm{C}-9), \delta 118.64$ (C-10), $\delta 135.67$ (C-10a), $\delta 136.73$ (C-11a), $\delta 130.11$ (C-11b).

\section{Conclusions}

The use of microwave irradiation provided an efficient, rapid and practical method for the synthesis of a methyl derivative of the indoloquinoline alkaloid cryptosanguinolentine. Higher yields were obtained for all intermediates as well as the final product.

\section{Acknowledgements}

We would like to thank the Durban University of Technology and the National Research Foundation for financial support of this work.

\section{References}

1. Sharaf, M.H.M.; Schiff, P.L.; Tackie, A.N.; Phoebe, C.H.; Martin, G.E. Two new indoloquinoline alkaloids from Cryptolepis sanguinolenta: cryptosanguinolentine and cryptotackieine. $J$. Heterocycl. Chem. 1996, 33, 239-243.

2. Cimanga, K.; De Bruyne, T.; Pieters, L.; Claeys, M.; Vlietinick, A. New alkaloids from Cryptolepis sanguinolenta. Tetrahedron Lett. 1996, 37, 1703-1706.

3. Karou, D.; Savadogo, A.; Canini, A.; Yameogo, S.; Montesano, C.; Simpore, J.; Colizzi, V.; Traore, A.S. Antibacterial activity of alkaloids from Sida acuta. Afr. J. Biotechnol. 2006, 5, 195-200. 
4. Ansah. C.; Gooderham, N.J. The popular herbal antimalarial, extract of Cryptolepis sanguinolenta, is potently cytotoxic. Toxicol. Sci. 2002, 70, 45-251; and the references cited therein.

5. Bierer, D.E.; Fort, D.M.; Mendez, C.D.; Luo, J.; Imbach, P.A.; Dubenko, L.G.; Jolad, S.D.; Gerber, R.E.; Litvak, J.; Lu, Q.; Zhang, P.; Reed, M.J.; Waldeck, N.; Bruening, R.C.; Noamesi, B.K.; Hector, R.F.; Carlson, T.J.; King, S.R. Ethnobotanical-directed discovery of the antihyperglycemic properties of cryptolepine: Its isolation from Cryptolepis sanguinolenta, synthesis, and in vitro and in vivo activities. J. Med. Chem. 1998, 41, 894-901.

6. Blinov, K.; Elyashberg, M.; Martirosian, E.R.; Molodtsov, S.G.; Williams, A.J.; Tackie, A.N.; Sharaf, M.M.H.; Schiff, P.L.; Crouch, R.C.; Martin, G.E.; Hadden, C.E.; Guido, J.E.; Mills, K.A. Quindolinocryptotackieine: the elucidation of a novel indoloquinoline alkaloid structure through the use of computer-assisted structure elucidation and 2D NMR. Magn. Reson. Chem. 2003, 41, 577-584; and the references sited therein.

7. Peczyriskc-Czoch,W.; Pognan, F.; Kaczmarck, L.; Boratyriski, J. Synthesis and structure-activity relationship of methyl-substituted indolo[2,3-b]quinolines: Novel cytotoxic, DNA topoisomerase II inhibitors. J. Med. Chem. 1994, 37, 3503-3510.

8. Sundaram, G.S.M.; Venkatesh, C.; Kumar, U.K.S.; Ila, H.; Junjappa, H. A concise formal synthesis of alkaloid cryptotackiene and substituted $6 \mathrm{H}$-indolo[2,3-b]quinolines, J. Org. Chem. 2004, 69, 5760-5762.

9. Jaromin, A.; Kozubek, A. Liposomal formulation of DIMIQ, potential antitumor indolo[2,3b]quinoline agent and its cytotoxicity on hepatoma morris 5123 cells. Drug Delivery 2008, 15, 49-56; and the references cited therein.

10. Kaczmarek, L.; Peczynska-Czoch, W.; Opolski, A.; Wietrzyk, J.; Marcinkowska, E.; Boratynski, J.; Osiadacz, J. Methoxy- and methyl-, methoxy- 5,6,11-trimethyl-6H-indolo[2,3-b]quinolinium derivatives as novel cytotoxic agents and DNA topoisomerase II inhibitors. Anticancer Res. 1998, 18, 3133-3138.

11. Molina, P.; Fresneda, P.M.; Delgado, S. Iminophosphorane-mediated synthesis of the alkaloid cryptotackieine. Synthesis 1999, 2, 326-329.

12. Molina, P.; Alajarin, M.; Vidal, A. New methodology for the preparation of pyrrole and indole derivatives via iminophosphoranes: synthesis of pyrrolo[1,2-a]quinoxalines, indolo[3,2c] quinolines and indolo[1,2-c] quinazolines. Tetrahedron 1990, 46, 1063-1078.

13. Fresneda, M.; Molina, P.; Delgado, S. A divergent approach to cryptotackieine and cryptosanguinolentine alkaloids. Tetrahedron Lett. 1999, 40, 7275-7278.

14. Trecourt, F.; Mongin, F.; Mallet, M.; Queguiner, G. Substituted 8-methoxyquinolines: regioselective bromination, coupling reactions and cyclization to an $11 \mathrm{H}$-indolo[3,2-C]quinoline. Synth. Commun. 1995, 25, 4011-4024.

15. Timari, G.; Soos, T.; Hajos, G. A Convenient synthesis of two new indoloquinoline alkaloids. Synlett 1997, 1067-1068.

16. Kumar, R.N.; Suresh, T.; Mohan, P.S. A photochemical route to synthesize cryptosanguinolentine. Tetrahedron Lett. 2002, 43, 3327-3328.

17. Dhanabal, T.; Sangeetha, R.; Mohan, P.S. Fischer indole synthesis of the indoloquinoline alkaloid: cryptosanguinolentine. Tetrahedron Lett. 2005, 46, 4509-4510. 
18. Dhanabal, T.; Sangeetha, R.; Mohan, P.S. Heteroatom directed photoannulation: synthesis of indoloquinoline alkaloids: cryptolepine, cryptotackieine, cryptosanguinolentine, and their methyl derivatives. Tetrahedron 2006, 62, 6258-6263.

19. Pitchai, P.; Mohan, P.S.; Gengan, R.M. Photo induced synthesis of methyl derivative of cryptosanguinolenine. Indian J. Chem. Sec.B. Org. Chem. Incl. Med. Chem. 2009, 48B, 692-696.

Sample Availability: Samples of the compounds are available from the authors.

(C) 2010 by the authors; licensee MDPI, Basel, Switzerland. This article is an open-access article distributed under the terms and conditions of the Creative Commons Attribution license (http://creativecommons.org/licenses/by/3.0/). 